\title{
Assessing the Service Quality and Customer Satisfaction on Islamic Banking by Using SERVQUAL Model
}

\author{
Muhammad Zulfaris Mohd Salleh ${ }^{1}$, Azwan Abdullah ${ }^{1}$, Noorshella Che Nawi ${ }^{1} \&$ Mohd Zulkifli Muhammad $^{1}$ \\ ${ }^{1}$ Universiti Malaysia Kelantan, Malaysia \\ Correspondence: Muhammad Zulfaris Mohd Salleh, Universiti Malaysia Kelantan, Malaysia.
}

Received: May 1, 2019

doi:10.5430/rwe.v10n2p79
Accepted: June 1, 2019

Online Published: July 8, 2019

URL: https://doi.org/10.5430/rwe.v10n2p79

\begin{abstract}
The quality services demanding by Islamic bank's customers are increased due to the increasing of customer's awareness on the quality services in Islamic banks. In evaluating the service quality, SERVQUAL instrument that divided by five dimensions which is reliability, responsiveness, tangibility, assurance and empathy will be used. So that, the main objective of this research is to investigate the impacts of (reliability, responsiveness, tangibility, assurance, empathy) on the satisfaction of the customer in the Islamic banking industry. The questionnaires are designed by adapting SERVQUAL model then distributed by employing the convenient sampling technique. Then, the data analysed using Statistical Package for Social Scientist (SPSS). The result indicated the relationship between assurance and empathy are very significance on customer satisfaction while reliability, responsiveness and tangibility are not significance on customer satisfaction.
\end{abstract}

Keywords: assessing the service quality, customer satisfaction, Islamic banking, SERVQUAL Model

\section{Introduction}

Nowadays, Islamic banks must compete with the other Islamic banks, foreign banks and conventional banks which also offered the services and products that fulfil the Islamic principles (Shariff, 2012; OLAOYE \& OLANIPEKUN 2018). There are very high competition in the banking industries due to the increasing of the commercial banks (Al-alak \& Tarabieh, 2011; Olowa \& Olowa 2017). However, regarding to the high competition among the banks have resulted to the better services provided by the banks in order to fulfil the customer's needs and wants (Shariff, 2012).In evaluating the service quality, SERVQUAL instrument will be used by the banks (Ilyas et al., 2013). The SERVQUAL instrument is developed by Parasuraman et al., (1988) in order to measure the service quality dimension and most of the researchers used this instrument in their researches. According to Parasuraman et al., (1988), SERVQUAL is divided into five dimensions which is reliability, responsiveness, tangibility, assurance and empathy. The banks management have to create the varieties ways to attract the customers and stay competitive in the industries (Kumar et al., 2011; Olanrele, 2018).

\section{Problem Statement}

Akhtar et al., (2016) mentioned, the poor demands of Islamic banks product due to the bad service quality provided where the managers cannot makes significant strategies for services. This statement supported by Rahim Abdullah in their previous studied in 1996, where the customer not satisfied with the attitude of staffs in delivering of services such as the attitude of staffs not polite, they are too busy, telephone line difficult to call and time work too limited. Hamzah et al., (2015) also indicated in their study where the staffs in Islamic banks are not very competent and have shown the bad attitude to the customers. Awan \& Azhar (2014) suggested in their study, the important capabilities like competencies, well communicate, confident, and have good attitude are the characteristics that Islamic bank's staff should have. This problems again highlighted by Lone \& Rehman (2017) in their study where the Islamic banks are very weak in assessing the customers' specific needs, which makes them unable to train their employees and tailor the products in parallel with these customers' needs. According to Thaker et al., (2016), since the number of Islamic banks is limited, existing banks should adopt online-based transaction in order to reduce the service inconvenience to customers. So that, Thaker et al., (2016) and Ali \& Raza (2015) suggest in their studies, Islamic banks should improve the qualities of services in fulfil the customers' needs in the various segment especially in credit cards facilities. 


\section{Research Objective}

The objective of this study is to investigate the impacts of (reliability, responsiveness, tangibility, assurance, empathy) on the satisfaction of the customer in the Islamic banking industry.

\section{Literature Review}

Parasuraman et al., (1988) claimed that, service quality is the judgement from the customers on the performance of the service quality in the sector of services. According to Daniel \& Berinyuy (2010), if the customers get the services below the expectation, they judges that banks have low quality and if the customers meet the high expectation, they judge that banks have high quality. The landscape changing of the Islamic banking had led the changing of the customers taste in demanding the better service quality that offered in banks (Abdullah et al., 2012; Olufemi, 2018). According to Shariff (2012), providing the best quality services to the customers is the important thing for the business survival. Ladhari et al., (2011) claim that, the services quality that provided by banks will influence the customer satisfaction and affected from that it also will influence the bank profitability. Based on Hamzah et al.(2015), the example of quality services that banks can provide include respect the customers by showing the good attitude to them, the capabilities of staffs to make the customers confident and trust on Islamic banks, very competent in handling the problems during the transaction, have a lot of knowledge especially about the Islamic banks, and well prepared in every situations happened. Based on Ahmed (2014), service quality play a big role while the customers select the banks. Besides that, Dusuki \& Abdullah (2007) also concluded, the service quality become a dominant factor while choosing the banks. According to Mahamad \& Tahir (2011), the deliverance of quality service, which can fulfil all needs and demands, also can attract the non-Muslims customer in choosing the Islamic bank.

\section{Hypotheses}

The hypothesis are as follow:

H1: The relationship between reliability and satisfaction of customer is positively significant.

H2: The relationship between responsiveness and satisfaction of customer is positively significant.

H3: The relationship between tangibility and satisfaction of customer is positively significant.

H4: The relationship between assurance and satisfaction of customer is positively significant.

H5: The relationship between empathy and satisfaction of customer is positively significant.

\section{Methodology}

The data was collected in Kota Bharu, Kelantan. The target population focused on the customers of Islamic banks in Kelantan. Respondents were selected by convenience sample, where the questionnaires that based on the SERVQUAL model were distributed during the visits of the customers to the banks. In total, there are 20 questionnaires distributed. Statistical Package for Social Science (SPSS) Version 22.0 is used to analyse the data that gathered.

\subsection{Data Collection Method}

For the primary data, this study used a survey approach and distribute the questionnaires to the respondents by employing the convenient sampling technique. The respondents were asked to answer the questionnaires based on a Likert-type scale, that ranged from $1=$ 'strongly disagree', $2=$ 'disagree', $3=$ 'neutral, $4=$ 'agree', and $5=$ 'strongly agree'. (Adis \& Jublee, 2010; Okon \& Monday 2017).

\section{Findings}

\subsection{Reliability Analysis}

Cronbach's Alpha statistic is used to analyse the reliability of the data. The value can be measured between 0 and 1 by using Cronbach's Alpha. The value that closer to 1 indicate the value become more reliable. According to Ulfat (2013), the value that showed between 0.738 and 0.813 can be considered good while the value below 0.60 cut off point, has no reliability in the coefficients. In this research, all the dimensions will be tested for the reliability. The overall reliability $(\alpha)$ of the scale was 0.787 and reliability of each dimensions were greater than 0.7 , which showed that the questionnaire was fit for analysis. Reliability of each dimensions are presented in the Table 1. 
Table 1

\begin{tabular}{llllll}
\hline Dimension & Cronbach's Alpha & $\begin{array}{l}\text { Cronbach's Alpha Based } \\
\text { on Standardized Items }\end{array}$ & $\begin{array}{l}\text { N } \\
\text { Items }\end{array}$ & of & Analysis \\
\hline Reliability & 0.845 & 0.843 & 5 & Reliable \\
\hline Responsiveness & 0.856 & 0.851 & 5 & Reliable \\
\hline Tangibility & 0.898 & 0.898 & 5 & Reliable \\
\hline Assurance & 0.907 & 0.907 & 5 & Reliable \\
\hline Empathy & 0.889 & 0.894 & 5 & Reliable \\
\hline Customer Satisfaction & 0.848 & 0.841 & 5 & Reliable \\
\hline Overall & 0.787 & 0.782 & 30 & Reliable \\
\hline
\end{tabular}

\subsection{Hypothesis Testing}

The column "Sig." holds the significance levels for the variables. As a rule of thumb, the coefficient is statistically significant if its p-value is smaller than 0.05 . So that, as mentioned in Table 2, there are significance correlation between assurance and empathy on customer satisfaction. While, there are no significance relation between reliability, responsiveness and tangibility on customer satisfaction.

Table 2

Coefficients $^{\mathrm{a}}$

\begin{tabular}{|c|c|c|c|c|c|c|}
\hline \multirow{2}{*}{\multicolumn{2}{|c|}{ Model }} & \multicolumn{2}{|c|}{ Unstandardized Coefficients } & \multirow{2}{*}{$\begin{array}{c}\begin{array}{c}\text { Standardized } \\
\text { Coefficients }\end{array} \\
\text { Beta } \\
\end{array}$} & \multirow[b]{2}{*}{$\mathrm{t}$} & \multirow[b]{2}{*}{ Sig. } \\
\hline & & $\mathrm{B}$ & Std. Error & & & \\
\hline \multirow[t]{6}{*}{1} & (Constant) & -.261 & .227 & & -1.153 & .268 \\
\hline & mean_reliability & .184 & .181 & .161 & 1.015 & .327 \\
\hline & mean_responsiveness & .248 & .138 & .239 & 1.800 & .093 \\
\hline & mean_tangibality & .150 & .115 & .150 & 1.309 & .212 \\
\hline & mean_assurance & .257 & .114 & .278 & 2.262 & .040 \\
\hline & mean_empathy & .231 & .095 & .245 & 2.441 & .029 \\
\hline
\end{tabular}

a. Dependent Variable: mean_performance

\section{Conclusion and Recommendations}

The results showed there are significance relationship between assurance and empathy on customer satisfaction while there are no significance relationship between reliability, responsiveness and tangibility on customer satisfaction. Actually, this study will contribute the benefit to the banks in order to improve the service quality thus can enhance the customer satisfaction on the Islamic banks. Besides that, the bank manager also will know the needs and wants that demands by the customers in order to improve the services offered. For the further research, non-Muslims can be made as a sample in order to identify their satisfaction on the Islamic banks. Besides that, the present research just represents a small sample size of the respondents and data. For a further research, the questionnaires and surveys should be distributed on a big sample in order to get results that are more accurate. Furthermore, the researchers should consider other determinants that can affect the customer satisfaction such as market orientation and innovation orientation. The idea of Islamic banking is new and the customers having less knowledge about Islamic banks, so that, the Islamic banks must develop innovative and strong marketing program to enhance the awareness about the Islamic products and services.

\section{References}

Abdullah, A. A., Sidek, R., \& Adnan, A. A. (2012). Perception of Non-Muslims Customers towards Islamic Banks in Malaysia. International Journal of Business and Social Science, 3(11), 151-163. Retrieved from http://ijbssnet.com/journals/Vol_3_No_11_June_2012/18.pdf 
Adis, A., \& Jublee, E. (2010). Market orientation and new product performance: The mediating role of product advantage. African Journal of Marketing Management, 2(5), 91-100. Retrieved from http://www.academicjournals.org/article/article1380537783_Abdul Adis and Jublee.pdf

Ahmed, T. (2014). Customers preference towards islamic banking: religious belief or influence of economic factor, 1-28. Retrieved from http://dspace.bracu.ac.bd:8080/handle/10361/3335

Akhtar, N., Shouqat, U., Raza, Al., Akhtar, H. M. A., Ijaz, M., \& Maqsood, T. (2016). Factors Affecting Customer Satisfaction in Islamic Banking in Pakistan, 610-619.

Al-alak, B., \& Tarabieh, A. S. M. Z. (2011). Gaining Competitive Advantage And Organizational Performance through Customer Orientation, Innovation Differentiation and Market Differentiation. International Journal of Economics and Management Sciences, 1(5), 80-91.

Ali, M., \& Raza, S. A. (2015). Service quality perception and customer satisfaction in Islamic banks of Pakistan: the modified SERVQUAL model. Total Quality Management and Business Excellence, 28(5-6), 559-577. https://doi.org/10.1080/14783363.2015.1100517

Awan, A. G., \& Azhar, M. (2014). Consumer Behaviour Towards Islamic Banking in Pakistan. European Journal of Accounting Auditing and Finance Research, 2(9), 42-65.

Daniel, C. N., \& Berinyuy, L. P. (2010). Using the SERVQUAL Model to assess Service Quality and Customer Satisfaction. An Empirical Study of Grocery Stores in Umea. Umea School of Business, 1-78. Retrieved from http://umu.diva-portal.org/smash/record.jsf?pid=diva2:327600

Hamzah, N., Ishak, N. M., \& Nor, N. I. M. (2015). Customer Satisfactions on Islamic Banking System. Journal of Economics, Business and Management, 3(1), 140-144. https://doi.org/10.7763/JOEBM.2015.V3.170

Hovens, J. (2013). Does Customer Perceived Risk Mediate the Relationship Between Service Guarantees and Customer Satisfaction?.

Ilyas, A., Nasir, H., Malik, M. R., Mirza, U. E., Munir, S., \& Sajid, A. (2013). Assessing the service quality of Bank using SERVQUAL model. Interdisciplinary Journal of Contemporary Research in Business, 4(11), 390-400. Retrieved from http://journal-archieves30.webs.com/390-400.pdf

Kumar, V., Jones, E., Venkatesan, R., \& Leone, R. P. (2011). Is Market Orientation a Source of Sustainable Competitive Advantage or Simply the Cost of Competing?- Journal of Marketing, 75(1), 16-30. https://doi.org/10.1509/jmkg.75.1.16

Ladhari, R., Ladhari, I., \& Morales, M. (2011). Bank service quality: comparing Canadian and Tunisian customer perceptions. International Journal of Bank Marketing, 29(3), 224-246. https://doi.org/10.1108/02652321111117502

Lone, F. A., \& Rehman, A. U. (2017). Customer Satisfaction in Full-Fledged Islamic Banks and Islamic Banking Windows: a Comparative Study. Journal of Internet Banking and Commerce, 22(s7). Retrieved from http://www.icommercecentral.com/open-access/customer-satisfaction-in-fullfledged-islamic-banks-and-islamicbanking-windows-a-comparative-study.pdf

Mahamad, \& Tahir. (2011). Perception of Non-Muslims towards Islamic Banking: A Pilot Study. Journal of Humanitarian, 16.

Okon, E. O., \& Monday, O. I. (2017). Empirical and evidence-based investigation: External debt, poverty and economic growth nexus. International Journal of Applied Economics, Finance and Accounting, 1(1), 37-47.

Olanrele, I. (2018). Revisiting Electricity-Economic Growth Nexus in Sub-Sahara Africa: Perspectives from Nigeria and South Africa. International Journal of Management and Sustainability, 7(3), 180-193.

Olaoye, C. O., \& Olanipekun, C. T. (2018). Impact of Forensic Accounting and Investigation on Corporate Governance in Ekiti State. Journal of Accounting, Business and Finance Research, 4(1), 28-36.

Olowa, O. A., \& Olowa, O. W. (2017). Rice Farmer and Capital Formation: A Case Study of Rice Farmer's Credit Cooperative in Itoikin, Ikosi-Ejirin LCDA, Lagos State. International Journal of Sustainable Development \& World Policy, 6(1), 1-8.

Olufemi, A. S. (2018). Measuring and Assessing the State of Technological Innovations and the Level of Interaction between Rice Processors and Stakeholders in Rice Processing Industry in Nigeria. International Journal of Business, Economics and Management, 5(6), 164-175. 
Parasuraman, A., Zeithaml, V. A, \& Berry, L. L. (1988). SERQUAL: A Multiple-Item scale for Measuring Consumer Perceptions of Service Quality. Journal of Retailing. https://doi.org/10.1016/S0148-2963(99)00084-3

Prifti, R., \& Alimehmeti, G. (2017). Market orientation, innovation, and firm performance-an analysis of Albanian firms. Journal of Innovation and Entrepreneurship, 6(1), 8. https://doi.org/10.1186/s13731-017-0069-9

Rahim Abdullah. (1996). Institusi Kewangan dan Pelanggan, 7. Utusan Malaysia.

Shariff, R. A. M. (2012). Service Quality in Islamic \& Conventional Bank in Malaysia. Durham E-Theses Online: http://etheses.dur.ac.uk/7315/. Retrieved http://etheses.dur.ac.uk/7315/1/Ros_Aniza_Final_Thesis_29_May_2013.pdf?DDD35+

Thaker, H. M. T., Khaliq, A., \& Thaker, M. A. M. T. (2016). Evaluating the Service Quality of Malaysian Islamic Banks : An Importance-Performance Analysis Approach. International Journal of Business and Information, 11(3), 341-364. Retrieved from http://ijbi.org/ijbi/article/view/183

Ulfat, S. (2013). Pairing of Customer' Satisfaction with Brand Consciousness and Price Sensitivity (A Feminine Study in Pakistan on Beauty Care Products' selection, Use and Satisfaction). Asian Journal of Business Management, 5(1), 144-152.

Wajdi Dusuki, A., \& Abdullah, N. I. (2007). Why do Malaysian customers patronise Islamic banks? Bank Marketing, 25(3), 142-160. https://doi.org/10.1108/02652320710739850 